\title{
Combining historical maps and censuses of Cyprus from the sixteenth to the twentieth century: A geospatial approach
}

\author{
Antonis Hadjikyriacou ${ }^{\mathrm{a}, *}$, Evangelos Papadias ${ }^{\mathrm{b}}$, Christoforos Vradis ${ }^{\mathrm{b}}$, Christos Chalkias ${ }^{\mathrm{b}}$ \\ ${ }^{a}$ Department of Political Science and History, Panteion University, Athens, and Center for Spatial and Textual Analysis, Stanford \\ University - ant.hadjikyriacou@panteion.gr \\ ${ }^{b}$ Department of Geography, Harokopio University,Athens-papadias@hua.gr,cvradis@hua.gr,xalkias@hua.gr \\ * Corresponding author
}

\begin{abstract}
The paper presents the preliminary results of an ongoing project that combines historical cartographic and economic sources on Cyprus through the employment of geospatial analysis. The main sources are: the 1883 trigonometrical survey of the island by Horatio Herbert Kitchener; the 1572 fiscal survey and 1832/33 property survey by the Ottomans; and the 1931 British agricultural census. The Ottoman and British censuses, different though they are and separated by three and a half centuries, provide vital information on production, economic activity, population, and toponymy. The project correlates this data with the detailed recording of topographical, hydrological, and land use features of the Kitchener map, which constitutes an extremely close depiction of Ottoman conditions given that the transformation of the countryside witnessed during the British colonial period was not yet initiated. This allows the identification of certain constants in the Cypriot environment and landscape. The paper presents the interdisciplinary methodological challenges the project has encountered and proposes a framework for the combination of these different datasets and their analysis in order to better record and understand certain long-term patterns in the Cypriot economy, environment and landscape. It uses viticulture as a case study for the visualisation of data to determine the spatial distribution of vines in the historical long term. Finally, the paper situates its conclusions within broader historiographical discussions on the historical development of viticulture in the Mediterranean.
\end{abstract}

Keywords: Cyprus, Kitchener map, Ottoman surveys, British colonial censuses, HGIS

\section{Introduction}

The paper presents the preliminary results of the "Economy, environment, and landscape in the Cypriot longue durée" project, hosted at the Department of Geography of Harokopio University, Athens, and funded by the Sylvia Ioannou Foundation. The project is based on cartographic and economic sources on Cyprus from the medieval to the modern period with the employment of Historical Geographic Information Systems (HGIS). Cartographic sources include the 1883 trigonometrical survey of the island by Horatio Kitchener. Economic data is extracted from the 1572 fiscal survey and the 1832/33 property survey covering the Ottoman period (1571-1878), while from the British colonial period the 1931 agricultural census is the only available source.

Cyprus presents an interesting case study that combines modern and pre-modern historical sources of cartographic and quantitative nature. The rich history of the island's cartography offers ample information from the various maps and charts produced over the centuries by the Venetian, Dutch, or French (Stylianou and Stylianou, 1980; Scutari, 2003; Baynton-Williams, 2016-2020). Kitchener's 1883 map is an excellent example of a modern trigonometrical survey that offers extremely accurate and detailed information given the technological tools of the time. Employing GIS tools for that period allows extensive analysis at various levels. Combined with quantitative data derived from Ottoman and British censuses, as well as supplementary data from the preceding (Venetian) and subsequent postcolonial period, these sources offer a promising and exciting synthetic collection of datasets through which the mapping of economic trends in the island's longue durée is possible.

The project builds upon two earlier research endeavours. The first one, undertaken in 2016 by Harokopio University and the Sylvia Ioannou Foundation, georeferenced and spatially analysed Kitchener's 1883 map to produce a web application permitting the interactive use of the map (https://gaia.hua.gr/kitchener/; Chalkias et al., 2017). The second project was hosted at the Institute for Mediterranean Studies, Foundation for Research and Technology-Hellas and was entitled "Mediterranean Insularities" (https://medins.ims.forth.gr/, 2014-16). Funded by the European Commission's Marie Curie Actions, the project employed HGIS methods to visualise economic data contained in the first Ottoman survey of Cyprus from 1572 (Hadjikyriacou and Kolovos, 2015; Hadjikyriacou, 2021). The current project synthesises between these two earlier research initiatives and brings in two more sources: the 1832/33 Ottoman property survey and the 1931 British census. Spanning a period of 350 years and dealing with very different kinds of sources, the project synthesises between them and employs different digital cartographic techniques to visually represent and geospatially analyse data. The objective is to provide insights into the trends and patterns of the Cypriot economy and correlating them to the environment and lan- 


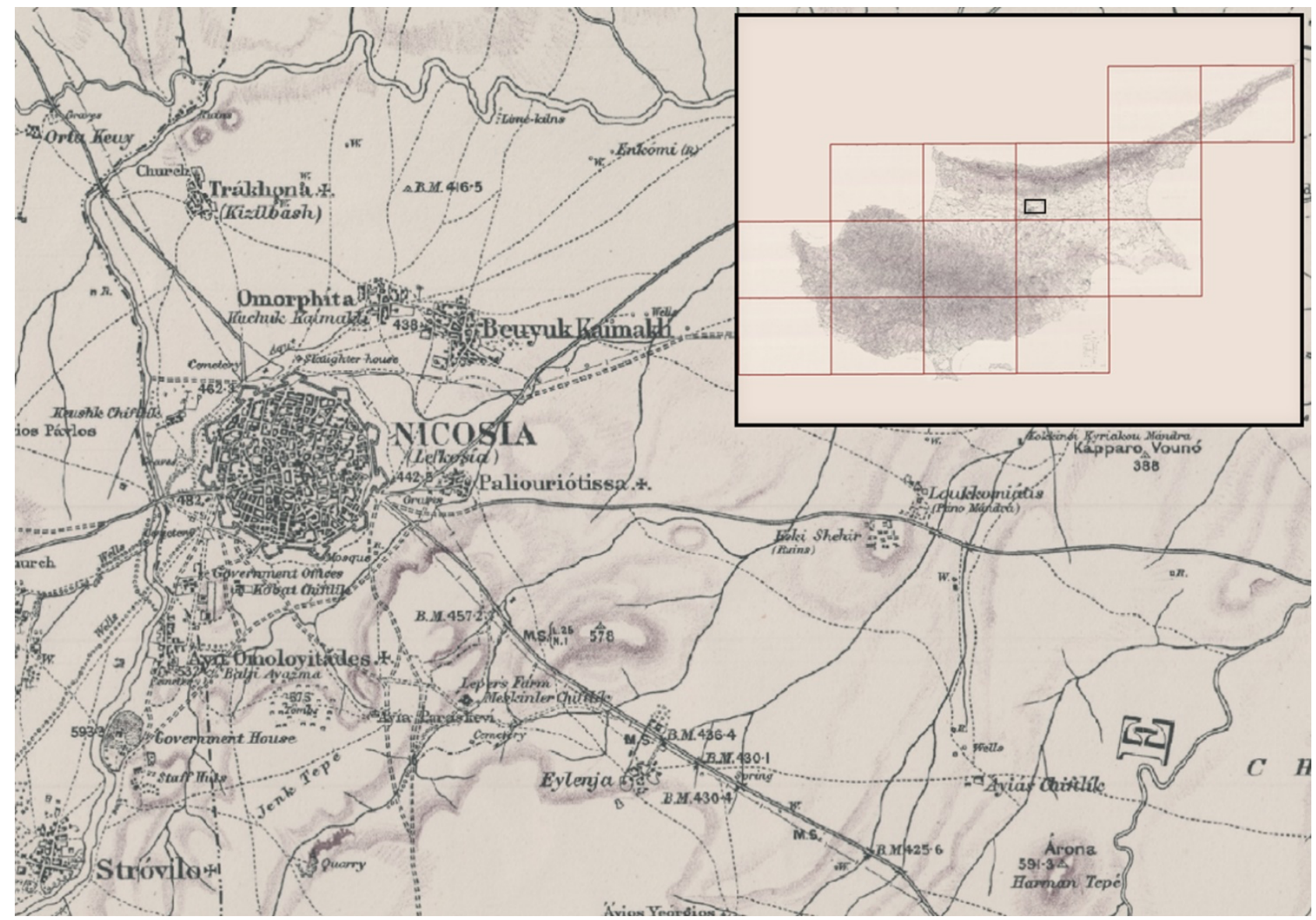

Figure 1. A detail from the Kitchener map showing Nicosia, the capital of Cyprus, alongside a mosaic of the fifteen sheets of the map

scape of the island.

This paper addresses the interdisciplinary and methodological challenges that the project encountered in order to synthesise between and analyse these very different kinds of sources and proposes a framework for the combination of these different datasets in order to better record and understand long-term historical change.

We begin our paper by briefly discussing the nature of the sources involved; we then move on to geocoding as the basis of this digital cartographic exercise; and conclude by focusing on viticulture. This is because it was the only economic activity that was recorded in a comparable fashion across all sources involved. The resulting analysis visualises the distribution of vine cultivation across the island as recorded in the sources examined.

\section{Sources}

\subsection{The 1883 Trigonometrical Survey by Horatio Kitchener}

In 1878, the Mediterranean island of Cyprus experienced a change in its administration. Though nominally still under Ottoman sovereignty (established in 1571 after a war against the Venetians), the island became a British protectorate in exchange for a tribute to the Sultan, as stipulated by the treaty of Berlin. The arrival of the British heralded the acceleration of several processes related to modernisation. Of particular interest are those related to knowledge-production and governmentality. Novel though they were, these methods did not appear out of the blue. Almost half a century earlier the Ottomans attempted a male population census, followed shortly thereafter by a land and property survey that was a landmark in the modernisation of the fiscal system.

One of the most emblematic innovations of the British was in the realm of cartography. The island's first governor, known as High Commissioner, Sir Garnet Wolseley, requested a rough map of Cyprus. The scale of this map for the use of the administration was set to one inch per mile $(1: 63,360)$. For the creation of this map, the then lieutenant, later Lord, Kitchener, arrived in Cyprus in 1878 together with some of the work teams and equipment,. By June 1881 more than $70 \%$ of the total land area $(2,600$ square miles), together with large-scale $(1: 2,500)$ city maps (Nicosia, Famagusta, and Limassol), had been recorded. By the end of 1881 most of the field work was essentially complete. The next step involved office work by drafting field measurements onto the map. By the end of 1882 cooperation with the Stanford publishing house had already started and by February 1883, Kitchener had completed the design and transcription of measurements, elevations and details to all of the sheets of the map, save one (Kitchener, 1883). Kitchener's trigonometric network has been used in subsequent surveying work and formed 
the basis for the development of the geodetic network still in use today.

The one-inch-to-the-mile-scale map consists of fifteen sheets plus the title sheet. In August 1879 Blackwood's Magazine published an article entitled 'Notes from Cyprus', in which the island is seen through the eyes of the 'occupying forces' (Notes on Cyprus, 1879). The information mentioned in this article was essentially what the work teams, under the guidance of Kitchener, were attempting to encapsulate in the map. The article notes the variance of landscape and climate on the island and stresses that changes in the landscape are many and extreme. It highlights how a clearing scorched by the sun easily turns into a pleasant cool shade of a tropical garden with running waters and olive, orange, fig and palm trees. It describes the dense pine forests and how riverside ferns are common land cover, noting further how the morphology of the terrain is characterised by steep slopes with many water sources that form a dense hydrographic network. According to the article, the northern part of the island is isolated by high mountains enclosing it, but the narrow strip of land between the mountains and the north coast is extremely fertile land, covered by carob and olive trees. Situated in strategic positions atop the mountains one finds the castles of St Hilarion, Buffavento and Kantara. There are streams running through alluvial or rocky terrain, while the water table is found at only $18-20$ feet. The article goes on to explain that the installation of some water mills would help irrigate large areas, instead of relying solely on rainfall. It earmarks the fertile plains, especially in the Paphos region, to point out that carry enough water for fruit farming. The article further observes that the agricultural resources of the island are rich, asserting that if appropriate practices were implemented the plains would be suitable for many crops, such as cereals and tobacco while vineyards are explicitly mentioned for their high productivity. It also points that the old wineries in the Akamas region indicate the suitability for vine cultivation, an area used for pasture at the time.

The article discusses what it sees as the island's shortcomings. One is the improvement of the road network and another is land productivity. It mentions the limited rainfall in 1879 (only 5 inches) and the resulting low yield to argue that even small- scale irrigation works would improve production.

As far as society is concerned, the article describes the two main ethnic groups living on the island, Greeks and Turks belonging to the two main religions of the island, Christianity and Islam. Also discussed is the 'administrative organisation' of the two communities, which it describes as run by the local Greek grandee landowners, who mainly choose to reside in the cities, and the Turkish rulers, who remain in the countryside. Finally, reference is made to the large, imprecisely recorded monastic property holdings of the Greek Orthodox Church and the substantial property owned by the mosques. The spatial distribution of all the above-mentioned elements of the physical and anthropogenic environment of Cyprus for this period is depicted in the so-called "Kitchener's map of Cyprus".

\subsubsection{Content of the map}

The cartographic layers of the map can be classified into five main thematic categories, each having their own subcategories (Table 1).

The first category includes the features associated with settlements, their name and place names in general. Where they exist, Greek and Turkish names of cities are provided on the map in the Latin alphabet. The size of font that was used for each settlement's name increases in line with population size.

Except for information relating to the size of settlements, the map provides information about the prevalent religion in each settlement. The prevalent religion is marked by a symbol (cross or upward crescent) next to the settlement's name. When the symbol of the cross or crescent appears to the right of the name, this suggests that the prevailing religion in this settlement was Christian or Muslim respectively. In any city or village where neither religion prevails, there is no symbol. It is not known whether Kitchener was following a certain percentage rule to ascertain that one religion prevailed over the other. However, the deciding factor must have been a substantially strong majority of believers of one religion for him to mark the settlement. It is reasonable to assume that he would have used a limit of approximately $3 / 4$ of the population. The various place names constitute their own sub-nomenclature. There are plenty of place names for mountains, regions, locations, capes, islets, etc. The way in which they were written refers mainly to the type and not the importance of the place name. Thus, names which refer to mountains and rivers appear not in horizontal alignment but inclined or curved for a more precise depiction of the location.

The second category of information identified in the map is that of networks and boundaries. It includes not only the road network existing during surveying but also roads under construction. Roads are further classified according to the period in which they were constructed. Roads built during British rule carry a different symbol compared to pre-existing ones. The large number of new roads shown

\begin{tabular}{|l|l|}
\hline Layer & Geometry \\
\hline Settlements, place & Point, polygon, line \\
names & \\
Networks and bounda- & Line, polygon \\
ries (Hydrographic net- & \\
work, roads, telegraph, & \\
administrative bounda- & \\
ries, coastline) & \\
Points of interest & Point \\
Land cover & Polygon \\
Morphology and relief & $? ? ? ? ?$ \\
\hline
\end{tabular}

Table 1 . Thematic layers and their geometry as they are stored in the geospatial database 
is consistent with the above-mentioned 'Notes from Cyprus' article, in which the lack of good roads on the island is highlighted as an issue requiring immediate attention. There is a substantial number of roads marked 'under construction', which indicates that Kitchener probably included roads that were in the planning stage as well. Overall, based on the rudimentary map indices, four types of road have been identified: three types of the rural road network and a fourth depicting the urban network, the roads existing within settlements. The hydrographic network is a sub-category of the general networks boundaries group. In relation to hydrography and irrigation, Kitchener's map provides information on the following networks: rivers with defined banks and riverbeds, main branches of ephemeral torrents, ephemeral subterranean streams, aqueducts and irrigation channels. Finally, the coastline, telegraph lines and administrative boundaries of regions and provinces recorded in the map are included in this sub-category of cartographic information.

A third category of geographic information presented in the map is associated with general points of interest. This includes information on places relating to culture (monasteries, churches, mosques, Islamic convents, cemeteries, ancient or later ruins, etc.), the economy (mills, sheepfolds, quarries, wells, etc.), but also those pertaining to the government, such as administrative buildings and military encampments.

The fourth category includes the cartographic information on land cover. The legend found on sheet 15 of the map does not provide any explanation of the land cover symbols used, except for the symbol depicting vineyards. This fact has a value of its own; however, to fully understand the map and to minimise approximations and interpretations of other symbols, we referred to the comprehensive legend of Kitchener's earlier map of Western Palestine. Using this map's legend as a guide, we identified the symbols of 6 broad and 18 specific landcover types appearing in the Cyprus map.

Finally, a fifth category of geographic information from the map refers to the morphology and the relief. Elevations have been recorded for each set of longitude and latitude coordinates of the island that, when combined with the hill shading of the relief, give a sense of island's terrain.

The pioneering aspects of Kitchener's map notwithstanding, there remain certain issues about what was or was not recorded on the map (for a critique, see Zesimou, 1998). These were the result not only of technical difficulties or challenges in the field (Shirley, 2001: 21; Chalkias et al. 2017: 53), but also of certain conscious or unconscious choices. For example, only seven mosques and three Islamic convents (tekkes) are recorded on the fifteen sheets of the map. There are valid technical reasons for this, namely that the cartography of urban settings where mosques (and churches) were more concentrated was dense, not leaving space for specific buildings. Indeed, in three other larger-scale maps $(1: 2,500)$ of the cities of Nicosia, Famagusta, and Limassol, churches and mosques are depicted in detail.
However, as far as the 1883 map is concerned, it has to be observed that there is a total of 808 churches, monasteries, and chapels throughout the island recorded. This is in sharp contrast to the ten Muslim places of worship that made it to the final map. Whether this discrepancy was the result of Kitchener's deliberate choice remains an open question given that the complete fieldwork notes from the survey are not extant. It may also be the case that these were choices made by Stanford in London during the printing process. Be that as it may, and regardless of whether these omissions were intended or not, there is a lot of information missing regarding Muslim places of worship.

\subsection{The 1572 Ottoman fiscal survey}

The Ottomans' detailed fiscal register of 1572 for Cyprus provides a snapshot of the Cypriot rural landscape on the morrow of the conquest. As such, there are very few Ottoman things contained within it. Or, more precisely, whatever was recorded reflected preceding Venetian conditions rather than subsequent Ottoman ones. From place names to district divisions, pre-Ottoman realities were left largely intact, as was standard Ottoman practice (Inalcik, 1954). The biggest source of rupture was the war and its consequences for the population, local infrastructure, and the economy at large.

This particular source belongs to the tahrir category of Ottoman registers. They have been evaluated and analysed as sources of Ottoman economic history since the 1930s and 1940s (Faroqhi, 1999: 97-101; Antov, 2017: 10-11) and have been the subject of long and fruitful debates concerning their use, interpretation, and reliability (Singer, 1994: 17-19; Lafi, 2018). Like any kind of fiscal data (whether modern or pre-modern), Ottoman state documentation is limited and does not accurately reflect the contemporary economy. Reconstructing trends and patterns in the economy from the assessments of state officials requires serious consideration of the challenges posed by data quality.

These registers were compiled upon the conquest of a new province and were updated periodically, albeit inconsistently. Surveyors assessed each village's average production over the preceding three years. Thus, the register did not report the precise production for 1572; but the data it contains provide an approximate indication of the longer term, since any given year could be exceptionally good or bad. In this sense, this 'inaccuracy' can actually benefit present-day economic historians (Cosgel, 2011: 89).

While such registers can supply information on demography, taxable production, economy, toponymy, or onomastics, the reliability of the data for examinations of each of these elements can vary significantly. The information contained reflects the concerns and questions of the Ottoman fiscal bureaucracy. For example, male heads of households (hane) formed the largest category of tax-payers. As a category, households varied significantly in time and place. Moreover, they should not be assumed to simply refer to a family, since a household was a fiscal, 
and by implication, a productive unit. Other taxpayers included widows, bachelors, elders, and people with different kinds of disability. Given the heterogeneous nature of this data, it is extremely difficult to use it for thepurposes of demography, despite previous attempts at calculating a multiplier pointing towards the total population (Ataman, 1992). Similarly, the villages and settlements listed are only those which paid taxes to the state; other land categories are not included, leaving significant gaps. Non-taxable products are also not registe-

\begin{tabular}{|c|c|c|c|}
\hline Category & $\begin{array}{l}\text { Type of } \\
\text { data }\end{array}$ & Unit & Value \\
\hline Subdistrict & Toponym & & Lefkoşa \\
\hline $\begin{array}{l}\text { Settlement } \\
\text { type }\end{array}$ & & & Village \\
\hline $\begin{array}{l}\text { Settlement } \\
\text { name }\end{array}$ & Toponym & & Epiho \\
\hline Households & Quantity & & 30 \\
\hline Bachelors & Quantity & & 2 \\
\hline Ispence tax & Mon. value & $\begin{array}{l}\text { Akçe (silver } \\
\text { coin) }\end{array}$ & 360 \\
\hline Wheat & Quantity & $\begin{array}{l}\text { Keyl } \\
\text { (weight } \\
\text { measure) }\end{array}$ & 200 \\
\hline Wheat & $\begin{array}{l}\text { Monetary } \\
\text { value }\end{array}$ & Akçe & 2,400 \\
\hline Barley & Quantity & Keyl & 200 \\
\hline Barley & Mon. value & Akçe & 1,200 \\
\hline Vetch & Quantity & Keyl & 10 \\
\hline Vetch & Mon. value & Akçe & 60 \\
\hline Broad beans & Quantity & Keyl & 8.5 \\
\hline Broad beans & Mon. value & Akçe & 85 \\
\hline Flax & Quantity & $\begin{array}{l}\text { Demet } \\
\text { (bundle) }\end{array}$ & 5 \\
\hline Flax & Mon. value & Akçe & 10 \\
\hline Pigs fine & Mon. value & Akçe & 30 \\
\hline Cotton & Quantity & $\begin{array}{l}\text { Kantar } \\
\text { (weight) }\end{array}$ & 1 \\
\hline Cotton & Mon. value & Akçe & 300 \\
\hline Olives & Quantity & Keyl & 2 \\
\hline Olives & Mon. value & Akçe & 22 \\
\hline $\begin{array}{l}\text { Vegetable } \\
\text { gardens tax }\end{array}$ & Mon. value & Akçe & 50 \\
\hline $\begin{array}{l}\text { Stray } \\
\text { animals duty }\end{array}$ & Mon. value & Akçe & 5 \\
\hline State taxes & Mon. value & Akçe & 15 \\
\hline $\begin{array}{l}\text { Charges and } \\
\text { fines }\end{array}$ & Mon. value & Akçe & 30 \\
\hline Total & Mon. value & Akçe & 4,567 \\
\hline
\end{tabular}

Table 2. The entry for the village of Epicho (Ott. Epiho) in the subdistrict of Nicosia (Kıbrıs Tahrir Defterleri, 2013: 465) ered. It is easy to see how a portion of economic production can fall into oblivion. For example, sugar, was not taxed because it was a state monopoly.

Historians have argued for different ways of utilising these documents. The positivism of early contributions was followed by varying degrees of scepticism in subsequent decades (Lafi, 2018: 104). The current consensus is that, despite their limitations, the registers may provide a valid foundation for our knowledge of rural society in the period (Singer, 1994: 17-19). The challenge is how to best utilise this rich corpus of data.

Digital humanities methods offer several advantages here. Traditional statistical methods do not sufficiently illustrate the spatial dimensions of economic data. As the following analysis will show, HGIS tools open up possibilities and reveal patterns that would otherwise be impossible to identify or even imagine. On a different level, traditional publishing methods which present masses of tabulated printed data are both impractical as well as expensive. Making data available in digital rather than printed form makes double-checking and further analysis much easier than manually copying data series from a book (Hadjikyriacou and Kolovos, 2015: 420).

What was the organisation of data in this register? Scribes and census-takers grouped the towns and villages by subdistrict (nahiye). After listing the names of tax-liable male heads of households or individuals of other categories (widows, bachelors, and various kinds of disabled persons, etc.) and the calculation of the monetary ispence tax, the register records the tithe for agricultural products in volume and monetary value, followed by other taxes for productive activities (e.g. gardens and orchards, watermills, taverns, tanneries, dye houses). Finally, recorded were also other fines and dues for which every village was responsible. In total, there were 51 categories of taxable products, fines, and dues. Finally, these entries record the total value of the revenue collected from each village.

Table 2 shows an example of an entry from the village of Epicho (Ott. Epiho), the first one to appear in the countryside of the sub-district of Nicosia.

With these general observations in mind, what may the source at hand tell us about the economy of the region we are examining? The register lists a total of 1,158 taxable villages and other settlements organized by subdistrict. Of these, 969 are villages for which a detailed account of the total quantity and value of taxed products is provided. The tithe (in-kind taxation of agricultural production) in this case was twenty per cent; multiplying this by five gives us the total amount of the assessment. The remaining 189 entries comprise categories such as city quarters, monasteries, farms, or other forms of land and fiscal units which were only assessed monetarily in lump sum and are thus excluded from the present analysis given their lack of information on agricultural products.

\subsection{The 1832/33 Ottoman property survey}

The next available source of similar depth, detail and scope came some two and a half centuries later (OA, 
ML.VRD.TMT.d.16152-5). It took the form of an ad hoc property survey, although it was miscatalogued in the Ottoman archives as being part of a novel typology of fiscal survey known as temettüat that aimed to modernise tax-assessment and collection. ${ }^{1}$ Recent research has demonstrated that this is not the case, and that the particular survey concerns the recording of the value and size of holding of lands, properties, and animals (Aymes, 2009).

The register was compiled in response to the significant non-Muslim population decline that alerted Istanbul the year before. As the documentation of the officer charged with compiling a preliminary settlement survey of 1832 declare, the usual 2:1 ratio of non-Muslims to Muslims had changed to the favour of the latter (BN, ST1042: 20 ). The decline in the number of Christian taxpayers (which, it has to be mentioned, is not the same as the population of the Christians at large), was due to any, or a combination of, the following reasons: (a) population flight to the neighbouring continental provinces in south Anatolia or northwest Syria; (b) conversions of Christians to Islam to escape the poll tax that was exclusive to the non-Muslims; (c) the registering of poverty-struck Christians as servants in commercial farms (çiftliks) or monasteries, which meant that they would not have to pay tax paupers; (d) the direct or indirect employment of local Christians in European consuls, which meant that they would enjoy foreign protection and, more importantly, tax exemption.

In other words, other than migration, the fall in taxpayer numbers did not necessarily entail actual population decline in real numbers. This is something we know because it was a recurring phenomenon in eighteenth- and nineteenth-century Cyprus, and in the cases where actual population decline was involved because of epidemics or some other disaster like an earthquake, this was explicitly mentioned. More interesting is the response of the Ottoman capital to the vicissitudes of taxable population: it located Cypriot migrants and offered tax-breaks for their return. This had less to do with their loss of revenue in Cyprus and more with the fact that the labour-intensive economy of the island (based on cereals, cotton, silk, and wine production) suffered greatly from the loss of manand woman-power. That this phenomenon was recurring meant that those who had fled to neighbouring coastlines returned to enjoy the tax-breaks only to leave a few years later on account of the once more negative economic and social conditions (Hadjikyriacou, 2011: 141-147).

The empire-wide 1831 male population census manifested the disruption of the usual 2:1 ratio, indicating worsening socio-economic conditions (Theocharides and Andreev, 1996). The Ottoman capital took an additional measure this time, which was the undertaking of a land and property survey. The production of knowledge on the state of the economy and society was a new measure to address the challenges of administration on the island.

Entitled Register of land and property on the island of Cyprus [Defter-i emlak ve arazl ... der cezire-i Klbrls], the survey was compiled in four volumes of 1,386 pages in total. There is a total of 792 geographic objects (districts, subdistricts, towns, villages, Islamic convents (tekkes), monasteries, etc.). Settlements are organised by district $(\mathrm{kaza})$ and subdistrict (nahiye), and then divided by town (kasaba), administrative centre (nefs), and village (kariye). Towns and large villages were also subdivided in their quarters. Monasteries, tekkes, çiftliks or other smaller settlements were recorded at the end of the lowest level of settlement category (i.e. villages or quarters).

There is one important lacuna in the register. For some unspecified reason, the Muslim inhabitants of Nicosia were not included unless they are recorded as absentee property-holders outside of the city. The possibility of missing pages from the register is excluded because the names of the Christian property-holders follows the opening statement declaring the purpose of the register. While in every other first page of the other three volumes and every other mixed settlement entry which opens with the Muslims (as the superior religion), the first page of the Nicosia register opens with the non-Muslims. It is also highly unlikely that a separate register would be compiled solely for the Muslim property-holders of Nicosia, for this would be a fraction of the other four registers. The most likely speculation as to why the Muslims of Nicosia are not included would have to revolve around the issue of property, given that this is purpose of the register. Yet, Muslim residents of Nicosia who hold property outside of the city are explicitly recorded as such. Such is the case of Mustafa son of Mustafa, resident of Nicosia, who owned property in the village of Kaimakli (Ott. Mesokelepsi nami diğer Ka'imakl1) (OA, ML.VRD.TMT.d.16152: 16). There are only 112 cases of Muslim residents of Nicosia who own property elsewhere, a fraction of the more than 2,500 adult Muslim males recorded in the 1831 male census (Karal, 1995: 161).

The main unit of the survey is the household (hane). Different kinds of Ottoman registers use the same term, but depending on the nature of survey concerned, it can be an entirely different kind of collective unit. For example, the household in a tahrir register (like the previous example examined in this paper) is not necessarily the same as a family household. The former is a fiscal-productive unit and the latter is a demographic one. Subsequent uses of hane for monetary (and not in-kind, as in the tahrir surveys) taxes such as avariz or cizye also have a different fiscal purpose and may not therefore be taken to be the same as a nuclear family. Along the same lines, we have to assume that the household in the Land and property survey is a property-owning one, for the only members of

1 The register has been published by the Ottoman Archives but only at the level of village totals of properties (Osmanl1 İdaresinde Kibris, 2000). Evangelia Balta and her associates have published the complete dataset all the way to the

household and individual level for four of the seventeen regions (the capital Nicosia, the districts and subdistricts) of the island. (Balta 2019; 2016; Balta, Oğuz and Özkul, 2015; Balta et al. 2011.) 
Properties shared between the imam of Larnaca

Mehmet Efendi son of Ali, and his brother.

\begin{tabular}{|cc|}
\hline \multicolumn{3}{|c|}{ House } \\
\hline 1 & Value \\
Rooms & 400 kuruş \\
\hline \multicolumn{3}{|c|}{ Ruined house } \\
\hline Rooms & Value \\
2 & 400 kuruş \\
\hline \multicolumn{3}{|c|}{ Grain field } \\
\hline Area & Value \\
250 dönüm & 1,275 kuruş \\
\hline \multicolumn{3}{|c|}{ Cotton field } \\
\hline Area & Value \\
3 dönüm & 90 kuruş \\
\hline
\end{tabular}

Properties shared between the imam, his stepmother and his sister

At the village of Pirga (Ott. Pirka)

\begin{tabular}{|cc|}
\hline \multicolumn{2}{|c|}{$\begin{array}{c}\text { Quantity } \\
32\end{array}$} \\
\begin{tabular}{|cc|}
\hline \multicolumn{2}{|c|}{ Value } \\
At the village of Anglisides (Ott. Anglisya)
\end{tabular} \\
\hline \multicolumn{2}{|c|}{ Olive trees } \\
\hline \multicolumn{2}{|c|}{ Quantity } \\
9
\end{tabular}

Table 3. The entry for the properties of the household of the Imam of Larnaca Mehmet Efendi, resident of the central quarter of Larnaca also known as Sotira (OA, ML.VRD.TMT.d.16153: 4).

the household that are explicitly mentioned are those who hold property (unless someone appears in order to define someone else, e.g. son of..., wife of..., but there is no way of knowing whether this person was alive). There is a total of 20,194 households recorded and 25,134 persons (heads of household who may or may not own property, propertyowning members of the household, or names of people used to define others).

What do entries look like? Following the district or subdistrict heading and the settlement name, individual property holders are recorded. Each household entry is introduced by the head of the property-owning household, and then the full or shared property of each other property holder is recorded. Table 3 shows the first entry of the central quarter (Mahalle-i Baș) of Larnaca, also known (nam-i diğer) as Sotira (Ott. Sodira). It concerns the household of the Imam of Larnaca (Ott. Tuzla) Mehmet Efendi son of Ali. When the location of the property is mentioned, it means that the property is outside of the holder's place of residence, where all other properties are found.

For the purposes of data-entry, we have codified the recording of property and land-holding in three main groups: overlying objects (buildings, trees), land use (by kind of cultivation), and animals. Unlike the 1572 fiscal survey which recorded the volume of taxable production, the $1832 / 33$ survey records the number of trees, the size of plots of land, buildings and structures, and livestock. Another difference which is worth mentioning is how cereals are being aggregated in the latter survey (grain for human consumption and fodder grain), which the 1572 one offers the data on the volume of each kind of grain individually (wheat, barley, vetch, oat, millet).

Given that the 1832/33 survey provides data at the individual property-holder level and does not simply aggregate it at the village level like the 1572 fiscal survey, the organisation of data was much more complex and required a more elaborate system than tabular data entry in a spreadsheet. Thus, by using the CIDOC CRM (http://www.cidoc-crm.org) as a conceptual guide we designed and developed an object-oriented web-based Content Management System using the Django web framework and the Python programming language. Overall, there was a total of 1,053 taxonomic categories and 233,514 entries. A group of research assistants (Zeynep Akçakaya, Yener Koç, Dimitris Giagtzoglou, Sefer Soydar, Nesli Ruken Han) transcribed and entered the data resulting to a total of more than $180,000 \log$ entries.

\subsection{The 1931 British agricultural census}

The arrival of the British in 1878 entailed the use of modern statistical methods for the measuring of population. During their seventy-two-year-long tenure, the British conducted eight censuses, most of which were in ten-year intervals, a pattern that was disrupted by the World War II and the armed insurrection of 1955-59: 1881, 1891, 1901, 1911, 1921, 1931, 1946, and 1960. Of these, only the one conducted in 1931 contains agricultural data. While the logic is quite close to that of the 1832/33 Ottoman survey in that it records overlying objects 
(buildings, trees), land use, and animals, land use is aggregated only to arable land and gardens. Another difference is that the British 1931 agricultural census only includes data on the total of each village, without recording individual or collective property-holders by name.

The compilers of the census expressed serious doubts on the reliability of the figures for three reasons: (a) that was the first time an agricultural census was conducted "and the returns made by peasants were, no doubt, influenced by a fear that the particulars asked for might be used for increased taxation" (Hart-Davis, 1932: 26); (b) despite British efforts to standardise the dönüm, the measure for area, it differed throughout the island (see below); (c) the holdings of monasteries, churches and other corporate bodies (presumably Islamic convents such as tekkes or zaviyes) were not included in the census.

Like the year of the census compiled about a century ago, 1931 was the continuation of preceding years of negative economic performance. The 1929 depression had severely impacted the Cypriot economy, as it was based on exportoriented agriculture. Declining prices of agricultural goods as a result of the Great Depression were coupled by drought in 1931. As a result, and very much like the two Ottoman surveys, we have to treat the 1931 census as an exceptionally negative conjuncture that in no way can be assumed to convey a sense of normal or average conditions.

Finally, one issue needs to be discussed with reference to the 1931 agricultural census, as well as the Ottoman 1572 and 1832/33 surveys. In all three sources land was recorded in dönüm, the Ottoman unit for area measurements. Like most Ottoman units of measure, it was not standardised until later in the nineteenth century. It varied greatly not only across the empire, but also within individual provinces. As discussed above, there were deviations in the assessment of the dönüm throughout Cyprus. The size of the dönüm varied not only in space, but also time. The Ottoman standard dönüm in the midnineteenth century was 919.3 sq. m (Inalcik, 1983: 340). The local Cypriot measure, known as skala in Greek, equalled 2.75 Ottoman standard dönüms, i.e. 2,528 sq. m. (Papadopoullos, 1980: xxii). Upon their arrival in Cyprus, the British determined the dönüm at 10,609 sq. ft., i.e. 985,61 sq. m. (The Cyprus Gazette, 1879: 14). This had subsequently changed, and in 1901 one Cypriot dönüm/skala equalled 14,400 sq. ft., i.e., 1,337.8 sq. m. (Hutchinson and Fisher, 1905: 474). In 1931 was set at $1,137.81$ sq. $\mathrm{m}$. It is unclear whether the dönüm used for the $1832 / 33$ surveys refers to the Ottoman standard measure or the local one. The above discussion is to demonstrate that comparisons between these sources should consider these deviations and not take the figures and conversions at face value.

\subsection{Supplementary sources}

As we discuss in the following section, identifying the geographic coordinates of extinct settlements was a major challenge. In order to identify (or at least estimate) the location of abandoned settlements, we used the following additional sources:

1. The 1542 map of Cyprus by Leonida Attar (Romanelli and Grivaud, 2006)

2. Toponymic data from four Venetian surveys published by Grivaud (1998) ${ }^{2}$

3. The 1862 map by Jacques Marie Joseph Louis de Mas Latrie

4. The 1831 male census of Cyprus (Osmanlı İdaresinde Kıbris, 2000)

5. The 1832 Ottoman settlement survey by Esad Efendi (BN Supplément turc 1042)

6. The Complete Gazetteer of Cyprus compiled by Menelaos N. Christodoulou and Konstantinos Konstantinou (1987)

\section{Geocoding}

Geocoding is a crucial aspect of mapping data. Identifying the geographic coordinates of settlements in a period that spans from 1572 to 1931 presents a major challenge in that during the sixteenth and seventeenth century a dramatic fall in the number of settlements was observed in Cyprus. Indicative is the gap between the 1572 and 1832/33 surveys: from 969 villages, towns, and quarters in the former survey there is a drop to 589 a bit more than twoand-half centuries later, i.e. a thirty-seven percent drop. Identifying these extinct villages required text-mining and searching across the four primary sources of the project, as well as the six auxiliary ones discussed in the section immediately above.

\subsection{Searching across different toponymic sources}

Excluding the well-known towns and villages of Cyprus, for which matching is a quick and straightforward process, finer granularity toponyms require manual searching across different sources which are in most cases available in an analog form. The limiting factor for geographic information science has always been data. In order to overcome these constraints and apply a semi-automatic model of searching for potential matches, analog data had to be digitized and georeferenced in a common coordinate reference system. For instance, The Complete Gazetteer of Cyprus is composed of about 61,000 placenames using MGRS (Military Grid Reference System) for the corresponding location and defining matches on the ground is an easy task. However, the map of Leonida Attar lacks a coordinate system and was designed without following any kind of modern cartography rules. Although this map looks like a sketch and cannot be compared in accuracy at any level with modern data, digitizing names in vector form and carefully implementing rubbersheeting spatial adjustment techniques can make their toponymic data searchable and provide valuable hints not only to search in other datasets but to disambiguate similar names to the search term also. The most important dataset in the

\footnotetext{
${ }^{2}$ For a critique see Arbel (2000).
} 


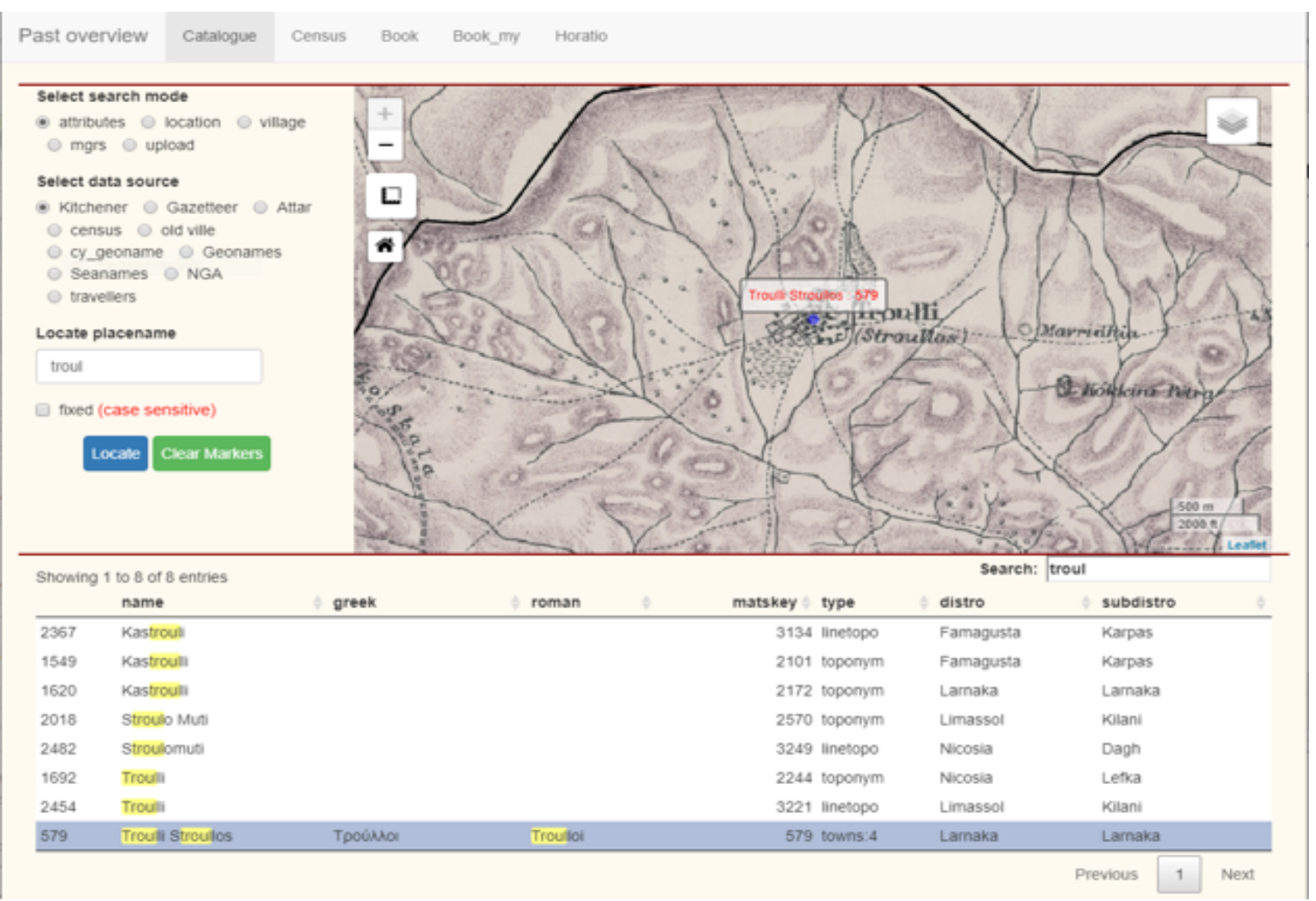

Figure 2. Screenshot of the application that allowed searching across the different toponymic sources.

procedure was the Kitchener map, and all datasets converged to its rich and detailed features.

An application allowing partial string matching of userdefined terms, with features registered in every available catalog was developed to address the issue. Additionally, the application user had the ability to look up to all potential matches to a term, in a table form and visualize them on demand on multiple map backgrounds the oldest being Kitchener's trigonometrical survey of the island. A spatial search was also implemented allowing the user to pick a location graphically on the map, find places inside a given radius and finally filter them using a term of his preference. That tool made Attar's approximate locations to guide us to features, ruins in most cases, designed on Kitchener's map or included in the Gazetteer, with similar names and finally match many features from censuses.

The main assumption in our case was that toponyms such as settlement names that have been used by people for some time are hard to be completely eliminated. Always some part of the name, or a variation thereof, remains in a nearby geographic feature such as a hill, a stream, a mountaintop or a church, because in many cases the name of a settlement originates from such a feature and vice versa.

\section{Mapping}

The four sources mentioned above include information about agricultural production. As the sources differ from each other, their data are also incompatible. The 1572 fiscal survey records the volume of taxable production, the number of animals, and some services; the 1832/33 property survey records the size of plots of land, the number of trees, housing, commercial, and agricultural built structures, and animals; the 1883 Kitchener survey cartographically represents some cultivations; and the 1931 agricultural census records land use, the number of trees, and the number of animals. The only agricultural activity for which comparable data exists in all four sources is viticulture. In what follows, we present the cartographic visualisation of the data in each of the four sources showing the spatial distribution of production or cultivation.

\subsection{Making meaningful comparisons between different sources}

For the purposes of the present analysis, we have chosen a point-based cartographic representation of the quantitative data from the surveys. This is the simplest and most descriptive way to show this data on the map. We made this choice because our primary objective is to compare the four sources. Other means of data representation (e.g. Thiessen polygons) are beyond the scope of this paper. This comparison will allow us to compare the distribution of the settlements engaged in viticulture in four very different snapshots of the Cypriot countryside. We have already noted that none of the sources we are examining is compatible with the others, apart perhaps from the 1832/33 

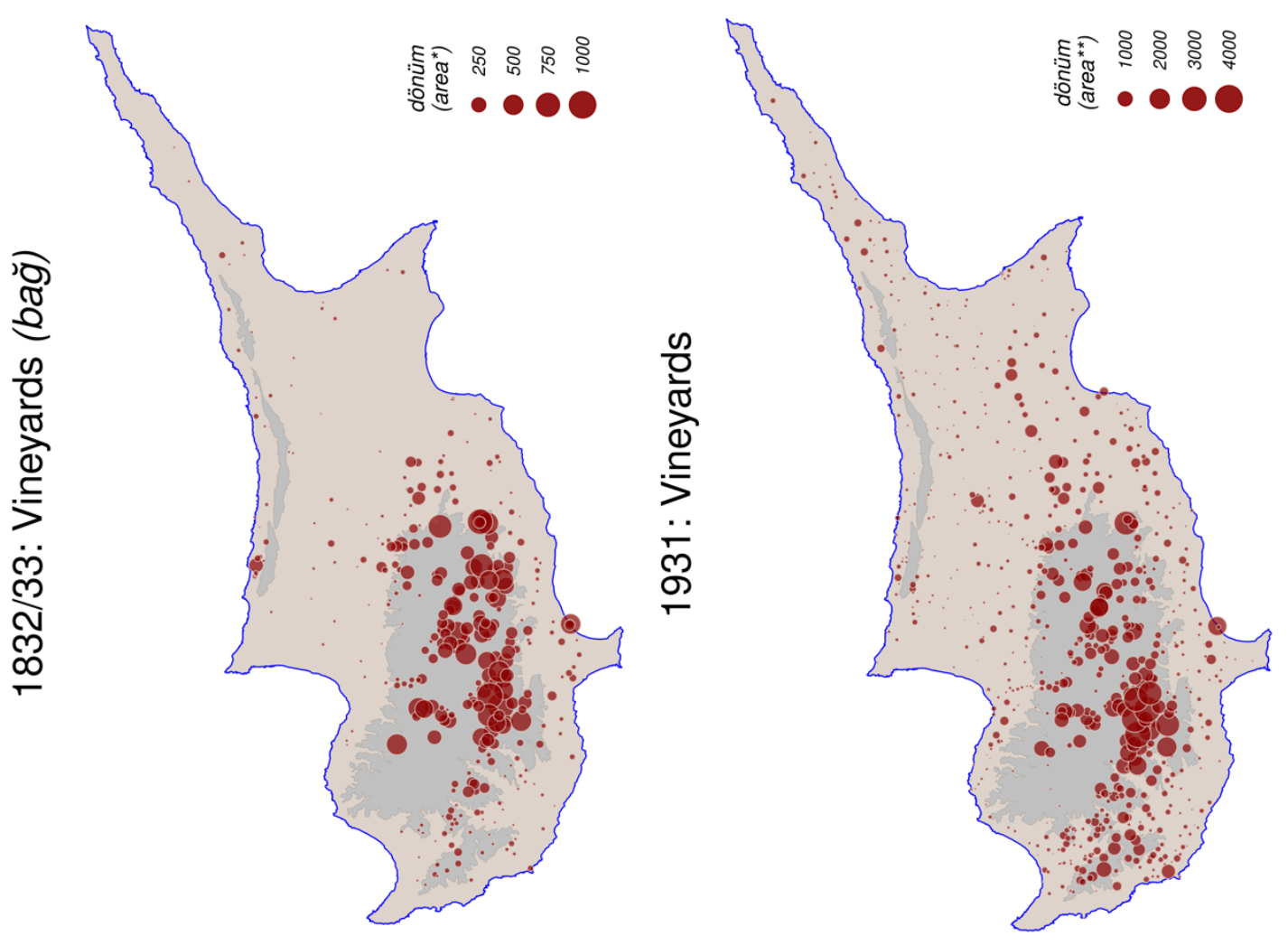

总
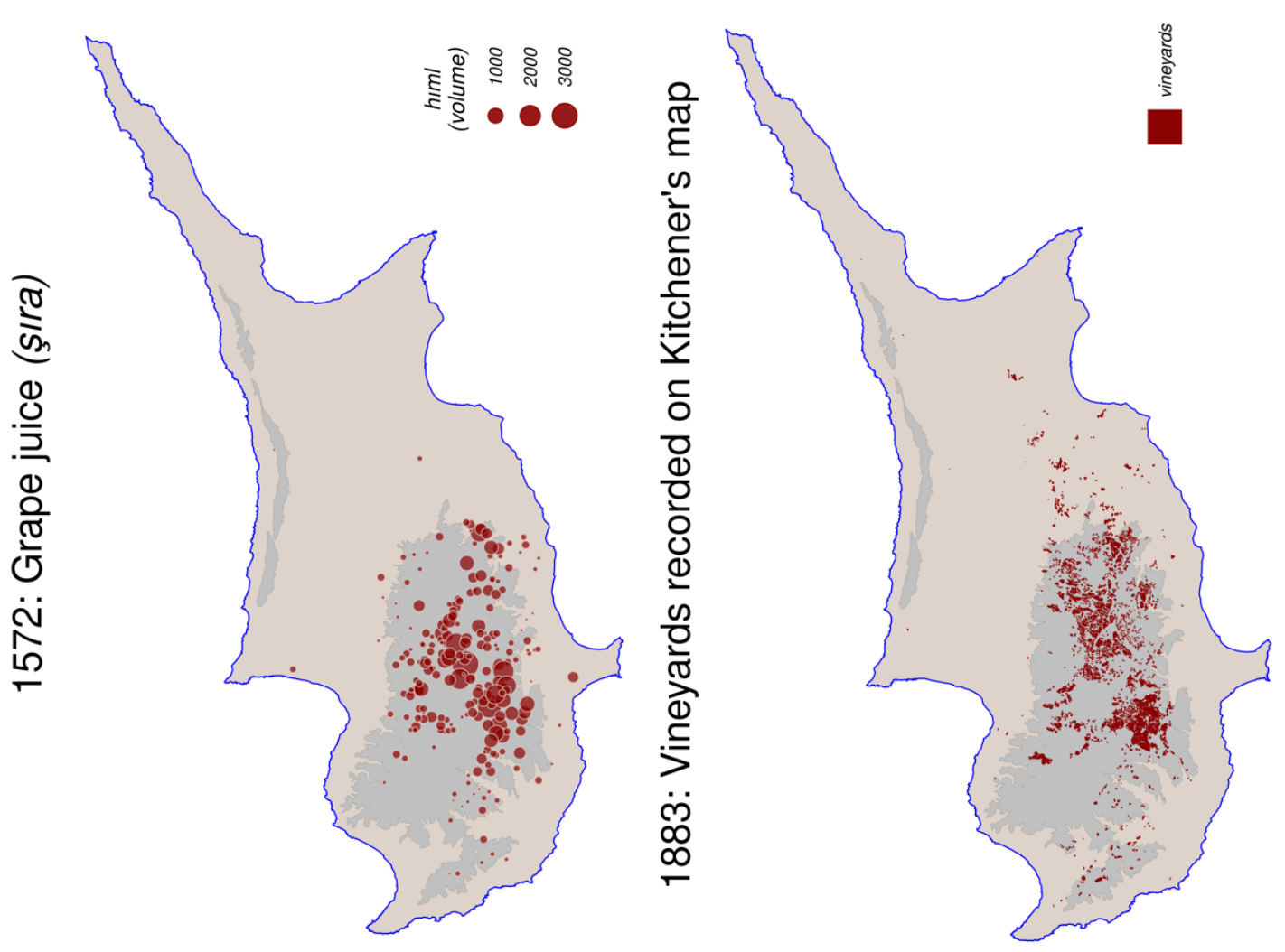

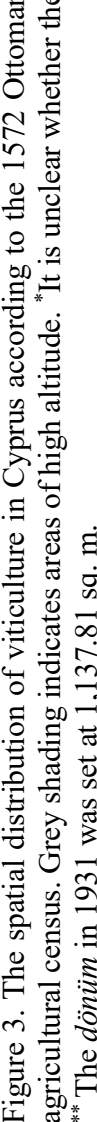

Proceedings of the International Cartographic Association, 3, 2021

8th International Symposium of the ICA Commission on the History of Cartography, 21-23 April 2020, Istanbul, Turkey (rescheduled for December 2021, Florence, Italy). This contribution underwent single-blind peer review based on submitted abstracts. 
Ottoman survey and the 1931 British agricultural census. Even in that case, however, it is unclear what the dönüm corresponds to in $1832 / 33$, unlike 1931 when it is set at $1,137.81$ sq. $\mathrm{m}$.. As a result, comparison in absolute figures of area using the same conversion unit is impossible (see discussion under 2.4 above).

A further challenge, as previously alluded, is the incompatible nature of the data. One source records taxable production, two of them land use, and another cartographically represents vineyards. Regarding the latter, we do not know if Kitchener was systematically recording viticulture throughout the island or if this was a selective exercise, meant to highlight the high concentration of viticulture thus leaving behind smaller and more sporadically distributed vineyards elsewhere. This is a reasonable question given that no other crop is recorded by name in the fifteen sheets of the map.

Finally, the temporal distance between these sources is also an issue. There is a major gap between 1572 and $1832 / 33$ that leaves us in the dark about what happened during these two-and-a-half centuries.

These problems do not preclude comparison. We examine the spatial distribution of viticulture as reflected in different kind of proxies, different though they may be. The following analysis limits itself on the patterns and trends that can be detected from a more abstract vantage point, rather than one that claims a (more) accurate and high-resolution perspective.

\subsection{The spatial distribution of viticulture in Cyprus, $1572-1931$}

Figure 3 shows the four snapshots of the Cypriot landscape in relation to viticulture $(1572,1832 / 33,1883,1931)$. The first observation concerns the proliferation of vineyards between 1572, 1832/33, and 1931. While there is no information on possible fluctuations between the sixteenth and the nineteenth century, there is a noticeable change in the expansion of vineyards. In 1572, viticulture was concentrated in the higher altitudes of or nearby the Troodos mountains. By 1832/33, we can observe a higher concentration in the southern slopes of the mountain range, but also an expansion to lower altitudes, further to the east, and some minor clusters throughout the island. A century later, and less than fifty years after the arrival of the British, we see the definite continuation of this trend, with higher concentrations in other regional clusters and the expansion of many more settlements where viticulture is introduced, if at a rather small scale (after 1832/33, at the very least). The Kitchener map of 1883 , an interim but very different snapshot, confirms the hight concentration in the southern slopes of the Troodos mountains, today a Protected Designation of Origin (PDO) area known as krasochoria (wine villages). The Kitchener map also confirms the eastward expansion of vineyards noticeable in the $1832 / 33$ survey.

Noticeable are also absences between the Kitchener map and the 1832/33 survey, given their close temporal proximity. The small cluster in the northern shore of the island is absent half a century later, and appears much smaller in 1931. If the assumption that Kitchener was not systematic in recording vineyards in other parts of this island is correct, this would explain this lacuna. Similarly, a small cluster in the 1572 survey in the north-western shores of the island shows the existence of vineyards which never appear again in the nineteenth- and twentiethcentury sources that we have examined.

\subsection{Beyond the shores of Cyprus}

Are there any broader implications to the above observations? How can the present analysis and cartographic visualisation shed light on bigger questions? The historical role of viticulture in the Mediterranean economy has been the subject of long and fruitful debates with many dimensions. Fernand Braudel had argued for the 'eternal trinity' of wheat, olive trees, and vines dominating the Mediterranean landscape. In an attempt to qualify this scheme, Triantafyllidou-Baladie has suggested that the shift from Venetian to Ottoman rule in Crete entailed a decline in viticulture under the shadow of olive cultivation, a less sophisticated crop in terms of its processing, making it more appropriate for a more (supposedly) archaic economy such as the Ottoman one (1988: 134). Molly Greene has refuted this view, showing how the rise in the importance of olive oil had its inception during Venetian times, while wine continued to play a prominent role in the economy of Ottoman Crete (2000: 119-120). In another attempt to revise Braudel, Faruk Tabak has contested that it was only after the seventeenth century that cereals, vines, and olive trees came to dominate the Mediterranean landscape that we know today (2008: 15). The present analysis confirms both Greene and Tabak. As far as the former is concerned, the proliferation of viticulture between the sixteenth and nineteenth century shows that there was nothing preventing the Ottomans from maintaining and growing the production of wine. The growing expansion of viticulture manifested in the cartographic visualisation of data lends support to Tabak's argument that widespread presence of vines in the Mediterranean landscape is a recent development and not a steady fature.

\section{Conclusions}

The present paper has attempted to demonstrate the benefits of the combined use of historical cartographic and quantitative sources through the means of geospatial analysis. It examined the 1572 Ottoman fiscal survey, the $1832 / 33$ Ottoman property survey, the 1883 Kitchener map, and the 1931 British agricultural census. Different and incompatible though these sources may be, and with a large temporal gap between the first and remain four ones, we have cartographically visualised the distribution of viticulture to identify the patterns and trends that may lend insights into the historical presence of vines on the island. Although we remain in the dark regarding the changes between the sixteenth and the nineteenth century, it becomes evident that while viticulture was concentrated in the higher altitudes of the Troodos mountains in 1572, it 
expanded in other regions by the 1830 s and continued to proliferate for the next century. This is something that lends weight to other historical arguments about the role and development of viticulture in the early modern and modern Mediterranean and Ottoman world.

\section{Acknowledgements}

Research for this paper was financially supported by the Sylvia Ioannou Foundation, and the European Commission's $7^{\text {th }}$ Framework Programme Marie Skłodowska-Curie Actions, as part of the MedIns: Mediterranean Insularities project (reference ID: 630030) hosted at the Institute for Mediterranean Studies, Foundation for Research and Technology-Hellas in Rethymno, Greece, between 2014 and 2016.

\section{References}

\subsection{Archival sources}

BN (Bibliothèque nationale de France, Département des manuscrits), Supplément turc (ST) 1042.

OA (Ottoman Archives, Istanbul, Turkey), ML.VRD.TMT.d.16152-16155.

\subsection{Secondary sources}

Antov, N., 2017. The Ottoman "Wild West": The Balkan Frontier in the Fifteenth and Sixteenth Centuries. Cambridge, Cambridge University Press.

Arbel, B., 2000. Cypriot villages from the Byzantine to the British period: Observations on a recent book. In

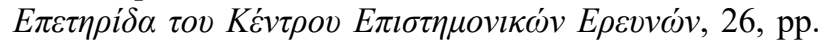
439-456.

Ataman, B. K., 1992. Ottoman Demographic History (14th-17th Centuries): Some Considerations. In Journal of the Economic and Social History of the Orient 35, pp. 187198.

Ayar, M. and E. Balta, 2012. Ottoman Larnaca in the age of reforms: a study of the Temettüat Register (1833). In E. Balta, T. Stavrides and I. Theocharides (eds), Histories of Ottoman Larnaca. Istanbul: Isis.

Aymes, M., 2014. A Provincial History of the Ottoman Empire: Cyprus and the Eastern Mediterranean in the Nineteenth Century. London, Routledge.

_ 2009. The port-city in the fields: investigating an improper urbanity in mid-nineteenth-century Cyprus. In Mediterranean Historical Review 24: 2, pp. 133-149.

Balta, E., ed., 2019. Ottoman Chrysochou (mid-19 th Century). Istanbul, Libra.

—, 2016. Ottoman Paphos. Population, Taxation and Wealth (mid-19th Century). Istanbul, The Isis Press.

Balta, E., M. Oğuz, and A. E. Özkul, 2015. Kouklia in Nineteenth Century Cyprus: On the Ruins of a once Glorious Paphos. Istanbul, The Isis Press.

Balta E. et al., 2011. Temettuat Defteri \#16153 (ML.VRD.TMT. \# 16153). Transcribed dataset < http://hdl.handle.net/10442/8703> Accessed 25 April 2021.
Cosgel, M. M., 2004. Ottoman Tax Registers (Tahrir Defterleri). In Historical Methods 37: 2, pp. 87-100

Chalkias, C. et al., 2017. Creation of the Cartographic Database and Development of a Web Application Presenting the Geographic Information of Kitchener's Map of the Island of Cyprus (edition of 1885). Athens, Harokopio University \& Sylvia Ioannou Foundation.

Christodoulou, M. and K. Konstantinidis, 1987. A Complete gazetteer of Cyprus. Nicosia, Cyprus Permanent Committee for the Standardization of Geographical Names.

Greene, M., 2000. A Shared World: Christians and Muslims in the Early Modern Mediterranean. Princeton, N.J., Princeton University Press.

Grivaud, G., 1998. Villages désertés à Chypre (Fin XXIIe-

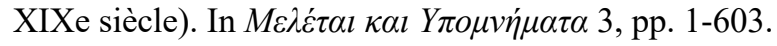

Hart-Davis, C. H., 1932, Report of the Census of 1931. Taken on April 27-28, 1931. Nicosia, F. S. Passingham.

Hadjikyriacou, A., 2021 (forthcoming). Economic Geographies. In Bernhard Struck, Riccardo Bavaj and Konrad C. Lawson (eds), Doing Spatial History. London: Routledge.

Hadjikyriacou, A. and E. Kolovos, 2015. Rural Economies and Digital Humanities: Prospects and Challenges. In E. Kolovos (ed.), Ottoman Rural Societies and Economies: Halcyon Days in Crete VIII. Rethymno: Crete University Press, pp. 415-421

Hutchinson, J. T. and S. Fisher, (eds.), 1905. The statute laws of Cyprus, 1878-1906: compiled in accordance with the provisions of the Reprint of Statutes Law. London, Waterlow and Sons.

Inalcik, H., 1954. Ottoman Methods of Conquest. In Studia Islamica 2, pp. 103-129.

— 1983. Introduction to Ottoman Metrology. In Turcica 15, pp. 311-48.

Karal, E. Z., 1995 (1943), Osmanli Imparatorluğunda İlk Nufüs Sayımı 1831. Ankara, Devlet İstatistik Enstitüsü.

Kıbrıs Tahrir Defterleri: Mufassal, Icmal ve Derdest. Tıpkıbasım, 2013. Ankara, T.C. Çevre ve Şehirlik Bakanlığı, Tapu ve Kadastro Genel Müdürlüğü, Arşiv Dairesi Başkanlığı.

Lafi, N., 2018. Organizing Coexistence in Early Ottoman Aleppo: an Interpretation of the 1518, 1526 and 1536 Tahrîr Defteris and the 1536 Qanunname. In Hidemitsu Kuroki (ed.) Human Mobility and Multiethnic Coexistence in Middle Eastern Urban Societies. Vol. 2, Tokyo, ILCAA, pp. 103-120.

Notes on Cyprus. 1879. In Blackwood's Edinburgh Magazine, 126: 765, pp. 150-157.

Osmanlı Idaresinde Kıbrıs: Nüfusu-Arazi Dağılımı ve Türk vakıfları, 2000. Ankara, T.C. Başbakanlık Devlet Arşivleri Genel Müdürlüğü. Osmanlı Arşivi Daire Başkanlığı.

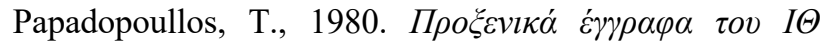

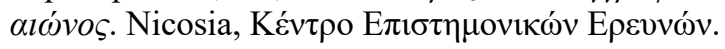


Romanelli, F. C. and G. Grivaud, 2006. Cyprus 1542: The Great Map of the Island by Leonida Attar. Nicosia, The Bank of Cyprus Cultural Foundation.

Shirley, R. W., 2001. Kitchener's Survey of Cyprus 1878 1883. The First Full Triangulated Survey and Mapping of the Island. Nicosia, Bank of Cyprus Cultural Foundation.

Singer, A., 1994. Palestinian Peasants and Ottoman Officials: Rural Administration around Sixteenth- century Jerusalem. Cambridge: Cambridge University Press.

The Cyprus Gazette, 13 (13 March 1879).
Tabak, F. 2008. The Waning of the Mediterranean, 1550 1870: A Geohistorical Approach. Baltimore, Johns Hopkins University Press.

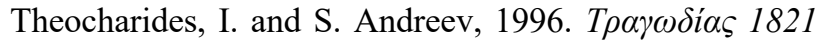

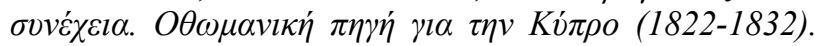

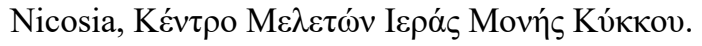

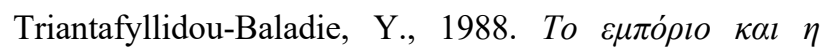

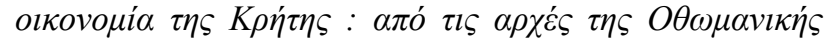

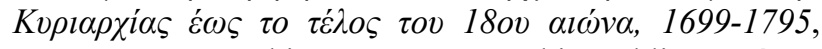
trans. M. Gyparakis \& A. Karastathi. Iraklion, $\Delta \eta \dot{\mu} \mu \varsigma_{\varsigma}$

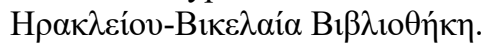

